\title{
Evidence of groundwater vulnerability to climate variability and economic growth in coastal Kenya
}

\author{
Nuria Ferrer ${ }^{1,2}$, Albert Folch ${ }^{1,2}$, Daniel Fernàndez-Garcia ${ }^{1,2}$, Mike Lane ${ }^{3}$, Mike Thomas ${ }^{3}$, John Mwangi \\ Gathenya $^{4}$, Calvince Wara ${ }^{3}$, Patrick Thomson ${ }^{5}$, Emilio Custodio ${ }^{1,2}$, Rob Hope $^{5}$
}

(1) Department of Civil and Environmental Engineering (DECA), Universitat Politècnica de

Catalunya (UPC), Jordi Girona 1-3, 08034 Barcelona, Spain

(2) Associated Unit: Hydrogeology Group (UPC-CSIC)

(3) Rural Focus Ltd., Kenya

(4) Soil, Water \& Environmental Engineering Department/Jomo Kenyatta University of Agriculture and Technology, Nairobi 62000, Kenya

(5) Smith School of Enterprise and the Environment, University of Oxford, United Kingdom

\section{Abstract}

Climate change and future abstraction regimes will influence the availability of groundwater resources. To alleviate any potential negative effects on aquifer systems and dependent industrial and human uses, it is important to develop long-term water management plans. This study evaluates the effect of climate change and future increased groundwater demand from a coastal aquifer located in Kwale County in southern Kenya. A previously calibrated numerical groundwater flow model has been used as an assessment tool to study how future climate (precipitation and temperature variation) and groundwater abstraction changes will affect the aquifer system. The groundwater flow model was built to simulate the period 2010 to 2017, and eight future model scenarios were developed that cover six hypothetical future years. Future groundwater abstraction has been based on current allocations and future estimates made by Kenya's Water Resources Authority. Future rainfall scenarios have been constructed based on a long historical data series (from 1959 to 2017) and the Standard Precipitation Index. The main results show that future abstraction increases due to economic growth exerts a minimum impact compared with expected climate variability. Recharge depends on intense rain events with important implications for both dry periods and for an average rainfall year. A succession of extended dry seasons may affect all water users. However, the groundwater level decline in the local shallow aquifer can 
27 reach five meters, with important consequences for local community water supplies. The most significant groundwater decline in drought periods is observed in the area surrounding the pumping wellfields in the deep

29 aquifers, where the effects of drought and significant abstraction are multiplied. However, the effect of 30 increased abstraction on the shallow aquifer system is limited. Despite groundwater level decline observed 31 during prolonged dry periods, a dry period followed by a humid period leads to the relatively swift recovery of 32 the groundwater system.

33

\section{Highlights}

Future scenarios of climate and abstraction developed for a coastal Kenyan aquifer

37 Future abstractions are not as important as climate change for groundwater resources

38 Local communities will suffer most from future climate variability

39 Intense rain events are crucial for significant aquifer recharge during dry periods

40 A drought followed by a humid period leads to a swift recovery of the system

\section{Introduction}

43 Climate change and future changes in abstraction affect groundwater resources. The uncertainty of possible

44 future impacts is a major challenge nowadays, given the urgency of adopting measures required to secure 45 drinking water supplies (Van Engelenburg et al., 2018). Global change and climate evolution seem to have 46 modified the hydrologic cycle and resulted in changes in precipitation pattern by increasing the frequency of

47 extreme events, such as droughts and floods, accelerating the melting of glaciers and icecaps, and modifying 48 soil moisture and river runoff (Bates et al., 2008). Forecast spatial and temporal changes in mean annual rainfall 49 are known to influence the water balance as a whole (Stocker et al., 2013), and groundwater recharge in particular (Carter and Parker, 2009). The effects of climate change will be even more serious in countries with

51 high population growth, which will generate an increasing demand for water resources (Carter and Parker, 
52 2009). This increased water demand will strain local water supply, limiting the amount of water available per 53 person.

54 During the past 40 years or more, numerical groundwater flow models have been proved suitable for evaluating 55 groundwater resources and testing alternative approaches for aquifer management (Howard and Griffith, 2009).

56 They are becoming increasingly useful and reliable tools when it comes to addressing the principal challenges 57 involved in planning and managing water resources, and are being widely applied (Barthel et al., 2005; Feng et 58 al., 2018; Folch and Ferrer, 2015; Mas-Pla et al., 2012; Urrutia et al., 2018; Vázquez-Suñé et al., 2006; Vižintin 59 et al., 2017, among others). Moreover, these models have been shown to constitute an important tool for 60 predicting the effects of climate change on aquifer behaviour (Kopytkovskiya et al., 2015; Levison et al., 2014; 61 Taylor et al., 2013; Werner et al., 2013) and for investigating mitigation measures (Howard and Griffith, 2009). 62 Despite their importance, developing climate change scenarios in groundwater models is difficult because the 63 scale of global climate models is large and the local historical data needed to predict future trends is typically 64 lacking. Most of these global climatic models are unable to accurately reproduce local historical climate 65 conditions, since they suffer systematic bias in the simulated variables (e.g., precipitation and temperature); a correction is therefore needed to obtain reliable local scale results (D’Oria et al., 2018).

67 Africa is considered the most vulnerable continent to climate change, with one-third of the population living in 68 drought-prone areas, with the highest rate of population increase in the world (Meigh et al., 1999), with 69 industrialization increasing as a result of different economic activities (mining, agriculture, tourism, etc.). One 70 of the key uncertainties surrounding the impacts of climate change in Africa is the effect on the sustainability 71 of rural water supplies (MacDonald et al., 2009). In East Africa, impacts on agriculture caused by climate 72 change will translate into impacts on livelihoods for the majority of people, as almost $80 \%$ of the population 73 depends on agriculture, which contributes $40 \%$ of the national gross domestic product (Adhikari et al., 2015). 74 Within this context, it is clear that it is necessary to develop long-term water management plans in Africa, to 75 address the consequences of the joint effects of climate change, population growth and increasing abstraction 76 in a continent where most people depend on groundwater for a range of different purposes (Abiye, 2016; Kahsay 77 et al., 2018; Taylor and Howard, 1996). 
78 Despite the importance of numerical flow models, they are rarely developed in sub-Saharan Africa, as the data 79 describing groundwater systems are often sparse and the current state of aquifer understanding is poor.

80 Furthermore, the effect that economic growth across the continent has on groundwater resources is in most

81 cases unknown or poorly understood. In some of the few studies available, Candela et al. (2014) evaluated the

82 effects of dry and wet periods on groundwater recharge in the Lake Chad Basin, a data scarce area, while

83 Yihdego et al. (2017) estimated seasonal variability of groundwater-surface water exchange fluxes on the water

84 balance of Lake Naivasha, in Kenya. Furthermore, despite the fact that hydrological processes in coastal areas

85 will be profoundly affected by climate change (Stefanova et al., 2015), there are only a few groundwater models

86 developed for the East Coast of sub-Saharan Africa so far. Kamermans et al., (2002) developed a coarse

87 numerical groundwater flow model to study the effects of groundwater discharge on the diversity and abundance of lagoon seagrasses, from the coast of Kenya to northern Tanzania, including Zanzibar.

89
The aim of this paper is to extend the emerging evidence of the implications of climate variability on recharge in Africa by including the impacts of economic development and associated abstraction. The contributions to the literature are methodological and empirical in developing future scenarios using numerical groundwater flow models with observed abstraction data and historical rainfall data. Furthermore, the analysis of groundwater level variation of the aquifer units in the study area provide insights into the potential vulnerability of rural communities who largely depend on the shallow aquifer. This paper is embraced as part of an interdisciplinary project that has the main idea that groundwater is essential for economic growth and can contribute to human development if resources are used sustainably to benefit the poor. Therefore, the aim of this project is to support interdisciplinary science and governance of managing groundwater risks for growth and development in Africa being one of the main requirement of the project the development of a numerical groundwater model to study the future effects of the climatic and social changes. To reach this requirement it has been needed to define the conceptual model of the aquifer system (Ferrer et al., 2019a) and identify the main water users in the area (Ferrer et al., 2019b).

\section{Methodology}

\subsection{Future scenarios}


104 In order to build future groundwater flow model scenarios to study which variables (rainfall, temperature, 105 and/or abstraction) are the priority concern in a study area, solving the 3D partial differential equation of 106 groundwater flow is needed. The governing equation for groundwater flow is:

$$
\frac{\partial}{\partial \mathrm{x}}\left(K_{x x} \frac{\partial \mathrm{h}}{\partial \mathrm{x}}\right)+\frac{\partial}{\partial \mathrm{y}}\left(K_{y y} \frac{\partial \mathrm{h}}{\partial \mathrm{y}}\right)+\frac{\partial}{\partial \mathrm{z}}\left(K_{z z} \frac{\partial \mathrm{h}}{\partial \mathrm{z}}\right)+W=S_{S} \frac{\partial \mathrm{h}}{\partial \mathrm{t}}
$$
where $K_{x x}, K_{y y}, K_{z z}$ are the values of hydraulic conductivity along the $x, y, z$ coordinate axes, which are assumed to be parallel to the major axes of hydraulic conductivity $\left[\mathrm{L} \mathrm{T}^{-1}\right] ; \mathrm{h}$ is the groundwater level $[\mathrm{L}] ; W$ are the source/sink terms, with $W<0$ for flow out of the groundwater system and $W>0$ for flow into the system [T $\left.{ }^{-1}\right]$;

111 Ss is the specific storage of the porous material $\left[\mathrm{L}^{-1}\right]$; and $\mathrm{t}$ is time [T]. The source code of MODFLOW is open 112 and easily accessible, and was used to develop the model.

113 The numerical model is used as a tool to study future scenarios which are calculated by incorporating a new 114 dataset for some of the boundary conditions in order to simulate the future/hypothetical years. In order to study 115 the effects of climate variables (temperature and precipitation) new rainfall and temperature time series are used to estimate the corresponding groundwater recharge for each land use, using the soil water balance approach.

117 The process followed is that detailed in Ferrer et al. (2019b). The results of the soil water balance are introduced 118 into the modelled period as a recharge boundary condition for the future hypothetical years.

119 The rainfall series was calculated based on the Standardized Precipitation Index (SPI) method (Guttman, 1999, 1998; Mckee et al., 1993). The SPI was developed as a versatile tool in drought assessment, analysis and monitoring to represent both short timescales (e.g., soil moisture status) and long timescales (e.g., reservoir and 122 groundwater storage). The SPI can be seen as the standard deviation of observed anomalies with respect to the 123 long-term average for the same period (month, season or year). The expected total rainfall depth is described in terms of terciles: "below normal" is rainfall less than the 33rd percentile, "above normal" is rainfall greater than 125 the 67 th percentile and "normal" is in between the $33 \mathrm{rd}$ and 67 th percentiles. Each scenario describes a sequence 126 of rainfall seasons that reflect a specific stress condition.

127 The SPI method has been used to characterize meteorological droughts over a wide range of timescales and 128 areas (Mckee et al., 1993). Values and their interpretation are summarized in Table 1. For the purpose of this 

"normal" and "above normal conditions".

\begin{tabular}{|c|c|c|}
\hline SPI Values & Classification & Lumped categories \\
\hline 2.00 and above & Extremely wet & Above Normal \\
\hline 1.50 to 1.99 & Very wet & \\
\hline 1.00 to 1.49 & Moderately wet & Normal \\
\hline-0.99 to 0.99 & Near Normal & \multirow{2}{*}{ Below Normal } \\
\hline-1.00 to -1.49 & Moderate dry & \\
\hline-1.50 to -1.99 & Severely dry & \\
\hline-2.00 and less & Extremely dry & \\
\hline
\end{tabular}

Table 1. SPI classification

132 The method requires the selection of a "primary" rainfall record to select specific seasons based on the SPI. The seasonal rainfall total depths and the SPI were calculated for each season. The mean monthly rainfall measured

134 indicates the seasons for specific areas. Each category considered 3-year scenarios with six rainfall seasons. 135 Four different rainfall scenarios were developed to reflect different degrees of deviation from a 3-year "normal" rainfall pattern. The "normal" scenario is compiled exclusively from seasons which fall in the normal category

137 (i.e. $-1.0<\mathrm{SPI}<+1.0)$. The "wet" scenario is compiled using rainfall seasons which fall in the "above normal" category (i.e. SPI $>+1.0$ ) and the "dry" and "very dry" scenarios compiled using dry seasons that fall in the "below normal" category (i.e. SPI $<-1.0$ and SPI $<-2.0$ respectively). After applying this methodology, rainfall data was spliced to form a synthetic time series of daily rainfall that reflects the rainfall conditions for each

141 scenario.

142 The temperature time series were generated using the same approach as for rainfall. The daily temperature data 143 for selected seasons were spliced together to obtain a 3-year time series. Once the temperature baseline time 144 series was built, two plausible temperature scenarios for the three selected rainfall stations were defined: $\mathrm{TC}_{0}$ 145 (Baseline temperature) and $\mathrm{TC}_{2}$ (Baseline temperature $\left.+2^{\circ} \mathrm{C}\right)$. 
146 In order to study the economic growth in an area, the abstraction boundary conditions need to be incorporated

147 with the future abstraction data. Firstly, the groundwater demand was disaggregated across different users and

148 aquifers. In the absence of actual measured abstraction data, the water permit allocation was used. Groundwater

149 permits ascribe a maximum daily abstraction rate for each borehole $\left(\mathrm{m}^{3} /\right.$ day). One plausible abstraction scenario

150 (referred to as D0) assumes that the total abstraction is equal to the daily allocated amount for 365 days per

151 year. A second scenario assumes that groundwater demand has increased (Scenario D2). This second future

152 estimation explicitly considers future population growth, since more people would imply more groundwater

153 consumption.

\section{$154 \quad$ 2.2. Field application}

155 The study area is located on the coastal plain of Kwale County, south of Mombasa and north of the Tanzania 156 border. This rural county is populated by over 720,000 inhabitants (GoK, 2013), with around $82 \%$ of people

157 living in rural areas. The climate is characterized by a bimodal rainfall pattern and experiences considerable 158 fluctuations. The "long rains" generally fall from April to June (AMJ), whilst the "short rains" occur between 159 October and December (CWSB, 2013). The driest months occur between January and March (JFM).

160 The conceptual model of the groundwater system is described in detail in Ferrer et al., (2019a). This aquifer 161 system encompasses two main hydrogeological units. An upper unconfined shallow aquifer, comprising young 162 geological materials, including carbonates, corals and sands (Pleistocene Fm.), and silicate sands (Pliocene Fm.)

163 (Fig. 1). These materials overlie Kambe and Mtomkuu Formations (Middle Jurassic to early Cretaceous), which 164 do not crop out, and comprise shales, sandstones and limestones. Beneath the Kambe formation there is a deeper 165 aquifer comprising sandstones (Mazeras sandstones of the Lower Jurassic), which outcrop in the Shimba Hills range in the west of the coastal plain. The hydrochemical facies of water samples and their environmental 167 isotopic characteristics indicate that there is hydraulic connectivity across the materials that compose the shallow aquifer and through the Mazeras sandstones (from the Shimba Hills to the deep aquifer). The Pleistocene Kilindini sands constitute the major part of the shallow aquifer system. The deep aquifer behaves

170 as a confined/semiconfined aquifer due to the intercalation of a low permeability aquitard between the young 171 and old materials. This confined aquifer is disrupted in the area by two palaeochannels (one in the north and 172 another in the south), that increase the connectivity between the shallow and deep aquifer in each of these zones. 
173 Indurated sedimentary and re-worked fluvio-deltaic materials make up the palaeochannel infill. The deep 174 aquifer is recharged laterally from the Shimba Hills, where it outcrops, and the shallow aquifer is recharged

175 directly by local rain. The discharge from both aquifer units is the Indian Ocean.

176 This aquifer system is exploited by human communities and industry. Scattered around the area there are over 177300 handpumps and 22 community wells providing drinking water to communities, health centres and schools 178 (Fig. 1). Furthermore, the study area has a long-established coastal tourism industry in the Ukunda/Diani zone, 179 with over 100 hotels. Tourism-supporting abstraction wells are located near the coast, mainly exploiting the shallow aquifer located in the Pleistocene corals (Ferrer et al., 2019a). Since 2012, two new and major waterreliant economic activities have been established in Kwale County. One is carried out by the Kwale International

182 Sugarcane Company Limited (KISCOL), which has been increasingly rehabilitating 5500 ha of irrigated 183 sugarcane. The other important recent economic activity is the country's largest mining operation: the Kwale Mineral Sands Project, operated by Base Titanium Ltd. While KISCOL takes groundwater from both aquifer units, Base Titanium only extracts groundwater from the deep aquifer (Ferrer et al., 2019a).
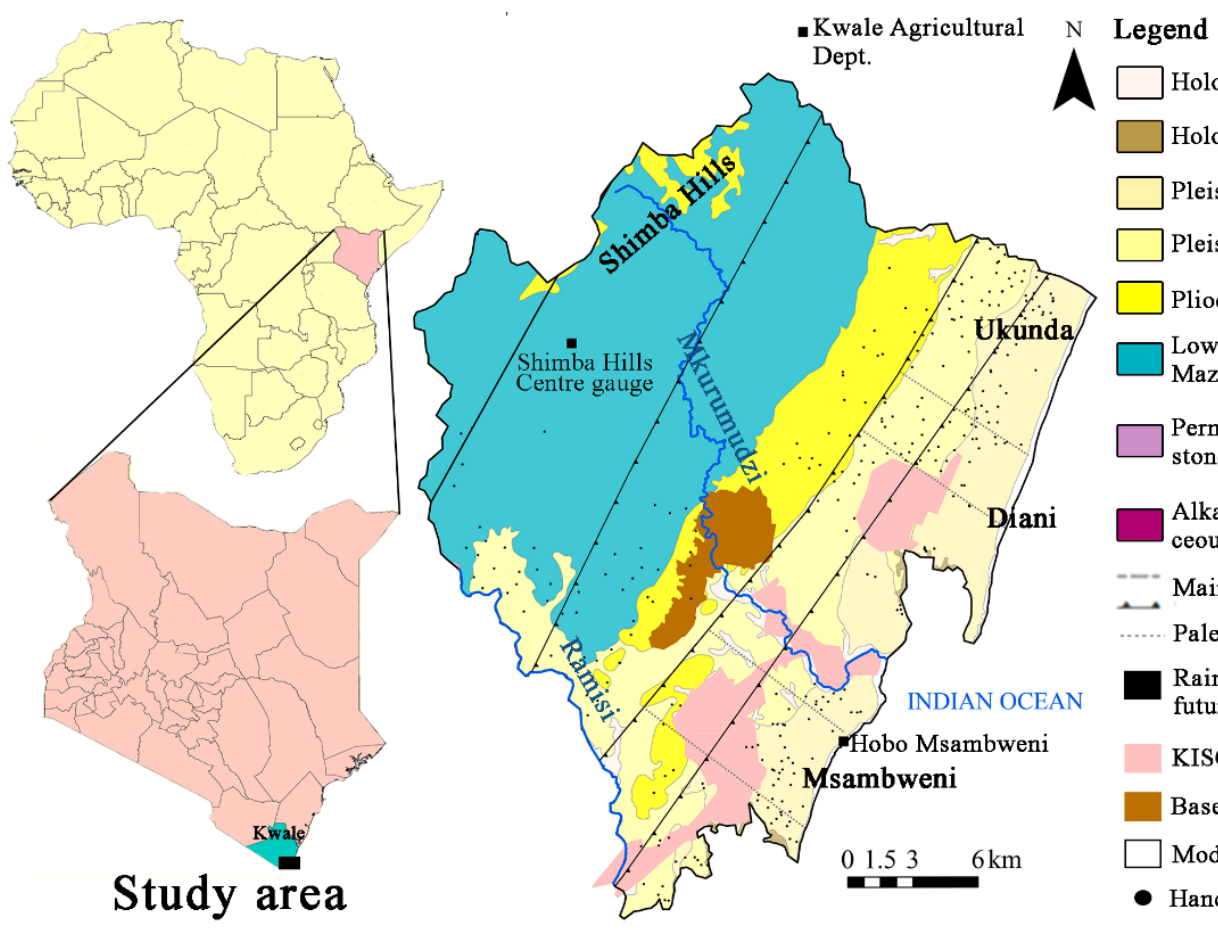

$\checkmark$ Holocene Alluvium Holocene Marine Deposits $\square$ Pleistocene Coral Limestones Pleistocene Sands Pliocene Magarini Sands Lower Jurassic Shimba Grits and Mazeras Sandstone Permo-Triassic Mariakani Sandstone and Maji-ya-Chumvi Beds Alkaline Intrusives (Cretaceous)

Main faults

...... Paleochannel borders

Rainfall station data used in future scenarios KISCOL-Sugar fields Base Titanium-Mining Site

- Handpumps 


\section{Groundwater model setup}

190 The groundwater flow model has been constructed using the MODFLOW-2005 Package and the graphical 191 interface ModelMuse (Winston, 2009). MODFLOW is a 3D code that solves the finite-difference method and 192 includes modules to simulate steady-state or transient groundwater flow in confined/unconfined aquifers 193 (Harbaugh, 2005). A steady-state simulation has been conducted to set up initial conditions, as compared with 194 field data. This steady state model was conducted with 2016 field data since the manual groundwater level 195 measurements started that year. To construct this steady state we have used the recharge values and the 196 groundwater withdrawal for that year. The transient simulation covers an eight year period from from 2010 to 197 November 2017. Monthly stress periods with 3 time steps in each have been adopted in the model simulation. Model grid and boundary conditions

199 The uniform finite difference mesh of the study area has been discretized in 120 columns and 99 rows, with a 200 size of $300 \mathrm{~m} \times 300 \mathrm{~m}$ per cell; thus, the model includes 11,880 cells and represents an area of $665.5 \mathrm{~km}^{2}$. The 201 vertical discretization extends from the ground surface, determined from a Digital Elevation Model with a 202 resolution of $90 \mathrm{~m}$ x $90 \mathrm{~m}$. Geophysical surveys at large scale using ERT (electro-resistivity tomography) helped 203 to define layer thicknesses and to improve the understanding of the geological structure.

204 The three aquifer units have been discretised in 16 horizontal layers. The first two layers represent the shallow 205 aquifer unit (Pliocene-Pleistocene Fms.). The next 10 layers represent the middle aquifer (Kambe and Mtomkuu 206 Fms). This layer is discretized in several layers to represent the two palaeochannels present in the study area, 207 one in the north and another in the south. The last four layers represent the deep aquifer (Mazeras sandstone) 208 (Fig. 2).

209 The model limits are defined by lateral boundary conditions and include the following two natural boundaries: 210 the coastline of the Indian Ocean to the east and the Ramisi River to the south. The sea level is defined by a 211 Dirichlet condition with the MODFLOW package CHD (Time-Variant Specific Head). The Ramisi River is 212 defined as a river condition. The other model boundaries are defined as no flow (Fig. 2). 


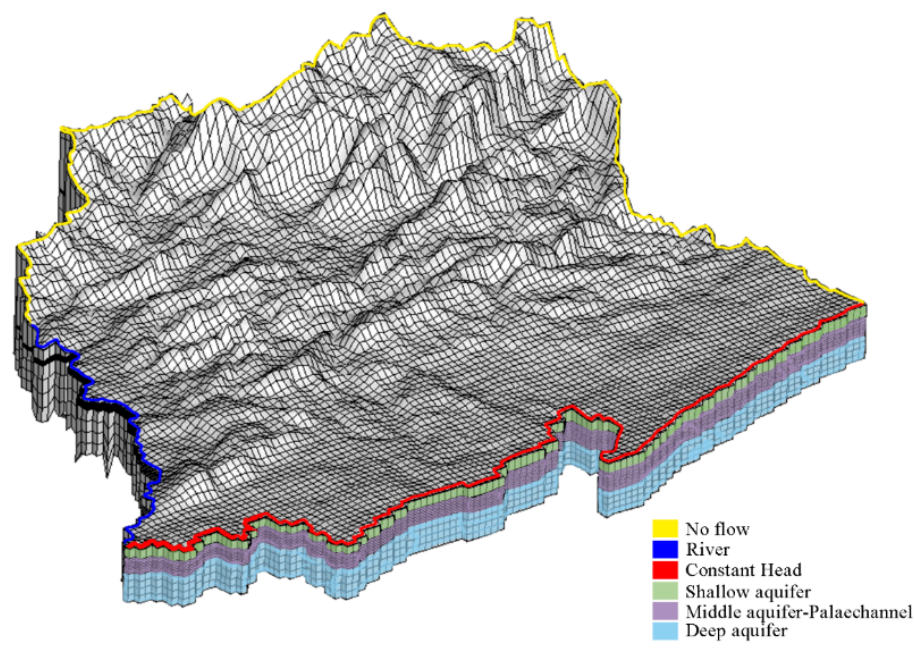

214 Figure 2. Modelled domain gridded with the boundary conditions to limit the model area. The cross section colours indicate 215 the discretization for the main aquifer units; shallow aquifer (green), middle aquifer/aquitard/palaeochannels (red) and 216 deep aquifer (blue).

217 Other defining conditions are used in the model: Recharge from precipitation. Groundwater recharge has been estimated for the modelled period (2010219 2017), for each land use and each soil type. This recharge has been calculated by soil water balance by 220 considering soil composition, root depth and the result introduced into the model as the main input. In order to 221 accurately define recharge values, field experiments have been carried out to verify that the soil properties data 222 base (KENSOTER) was correct. In addition, historic rainfall data from an established climate station has been 223 used, as well as rainfall data from new manual rainfall stations established by the study. The process followed 224 and the data used to calculate recharge is detailed in Ferrer et al. (2019b). Groundwater abstraction. A large number of pumping wells have been defined to describe the groundwater abstraction using the WEL package. The main groundwater abstraction is carried out by the main 227 economic activities in the study area: mining, irrigated sugarcane and factory, and hotels. Not all water users 228 exploit the same aquifers layers. The community wells, handpumps and hotels mainly abstract groundwater 229 from the shallow aquifer while the mining activity exploit the deep aquifer. The sugarcane company exploit 230 both aquifer. The companies in the study area (mining and sugarcane) pump to its full permit allocation pretty 
231 much all the time The abstraction rate for each economic activity, plus the community boreholes and 232 handpumps, are detailed in Ferrer et al. (2019b).

Surface/groundwater interaction. The perennial rivers in the study area (the Ramisi and Mkurumudzi

234 Rivers) have been defined using the RIV package, which calculates water exchange between the rivers and 235 groundwater. The river bed conductance has been defined by calibration and was set at $12 \mathrm{~m} / \mathrm{d}$. Small ephemeral 236 surface water flows have been defined using the DRAIN package, since flows only occur during intense rainfall 237 events. This type of boundary condition only allows groundwater discharge to rivers when groundwater level 238 is higher than the river channel. The drain conductance has been defined by calibration and was set at $55 \mathrm{~m} / \mathrm{d}$ 239 for all drains.

240 The hydraulic parameters have been divided into zones, based on geological formation (Supplementary 241 material). Due to the lack of hydrogeological parameters, the transmissivities for the main geological formation 242 have been obtained from boreholes drilled during the 1980s to the mid-1990s (thanks to the first-large scale 243 deployment of the Afridev handpump). The Afridev is a lever-action reciprocating handpump, originally 244 designed to be maintained at the village-level and capable of a pumping lift of up to $45 \mathrm{~m}$ (Baumann and Furey, 245 2013). The Swedish International Development Cooperation Agency (SIDA) played a critical role in financing 246 the programme. The transmissivity for each borehole has been calculated from specific capacity, using the 247 Galofré equation (1966) (Custodio and Llamas, 1976) taking the LPS (litre per second) test data and calculating 248 the difference between the static and dynamic groundwater level obtained during borehole testing. The 249 transmissivities have been complemented with hydrogeological data obtained during Base Titanium borehole 250 drilling and pumping tests in the deep aquifer system. Horizontal hydraulic conductivities ( $K y$ and $K x)$ have 251 been set, while the vertical component $(\mathrm{Kz})$ has been fixed as $10 \%$ of the horizontal hydraulic conductivities. 252 In order to simulate the effect of the low permeability barrier behind the indurated corals located adjacent to 253 Kilindini Sands, a HFB (Horizontal Flow Barrier) package has been used. This package simulates thin, low254 permeability vertical geological features that impede horizontal groundwater flow. Given that changes in 255 hydraulic heads are negligible compared to the saturated thickness, all model layers are assumed to behave as 256 confined units (constant transmissivity). 
257 A steady-state simulation for the year 2016 has been used to conduct a first calibration of hydrogeological 258 parameters and determine the initial heads of the transient simulations. The transient simulation covers the 259 period 2010 to 2017, though the period most representative of the mass balance is from 2014 to 2017; from 2602010 to 2013 the water balance is based on simulated heads affected by unknown initial heads. Fortnightly 261 groundwater head data from 34 observation shallow wells measured from 2016 to 2017 and groundwater heads 262 measured in Base Titanium water resources monitoring network (ten deep boreholes and 18 shallow boreholes) 263 from 2012 to 2017 have been used to calibrate the model (the plotted raw data is presented in Ferrer et al., 264 2019a). The hydraulic conductivity and the specific yield values have been calibrated manually. The root mean 265 squared error (RMSE) has been selected as an indicator of goodness of fit.

266 Due to the uncertainty of some GWL measurements in some hand-dug wells, different weights have been 267 defined by type of water point: lower weights have been applied to hand-dug wells and higher weights to 268 piezometer wells installed by Base Titanium, as the screened sections are well-defined. Results show that the 269 simulated GWLs match most observed GWLs, with RMSE=4.28 meters. This RMSE is different for each of 270 the geological grouping of wells being a RMSE $=1.82$ meters for the wells located in the Pliocene sands, 271 RMSE $=3.72$ meters for wells located in Pleistocene sands, RMSE $=6$ meters for the wells located in the deep 272 aquifer and finally the low RMSE $=1.45$ meters for the wells located in the Pleistocene corals. The main 273 calibrated hydrogeological parameters (i.e., $K x$ and $S s$ ) are presented in Table 2. 


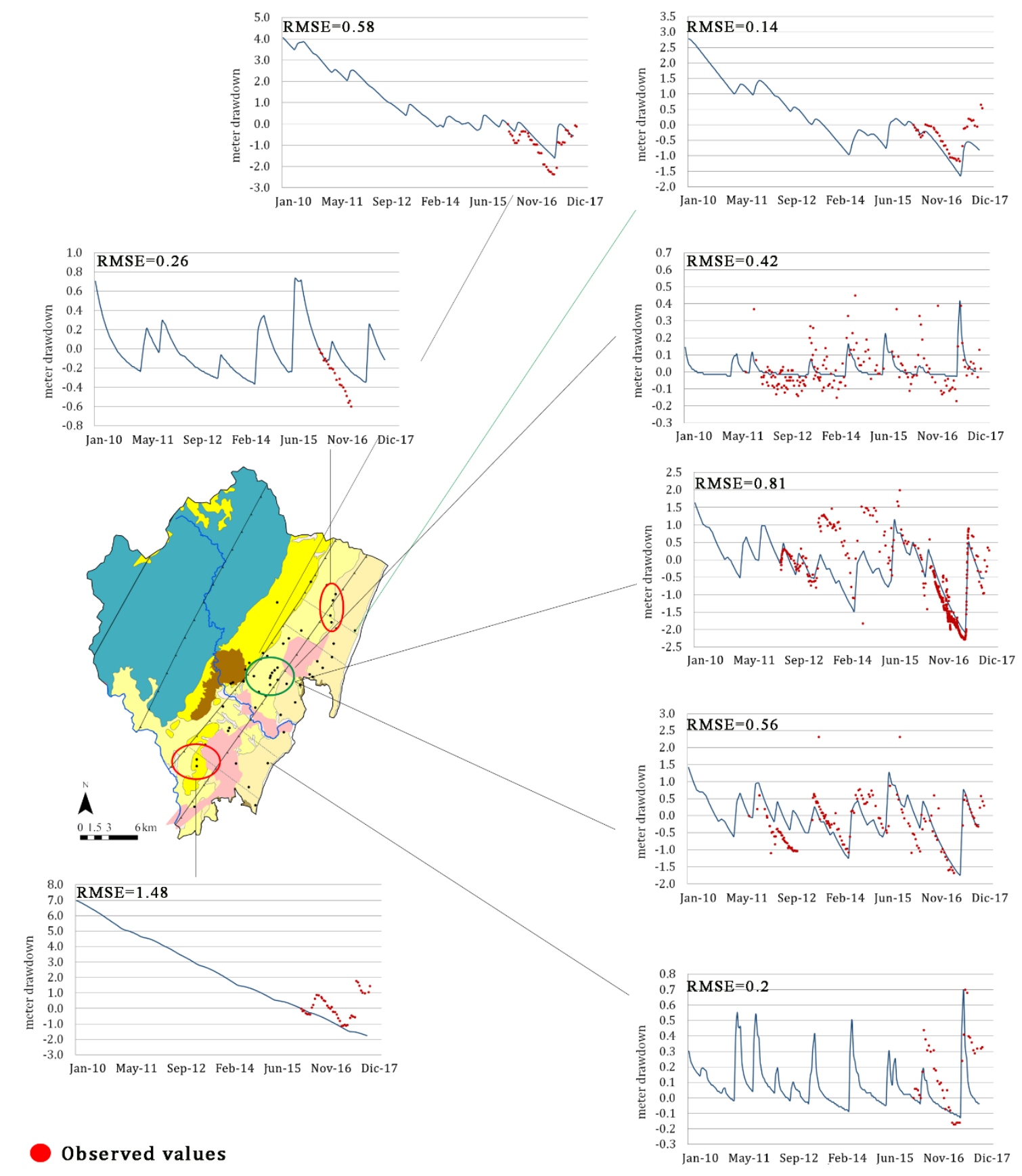

275 Figure 3. Observed values (red dots) versus calibrated values (blue line) of some representative wells for each 276 geological formation. The red circles are the areas with less effectively calibrated groundwater drawdowns.

277 The green circles are the Base Titanium shallow piezometers with good fit. The units of the RMSE are meters. 


\begin{tabular}{|c|c|c|}
\hline Geological formation & Hydraulic conductivity (K) in & Specific storage (Ss) in $\mathbf{~ m}^{-}$ \\
\hline m/day & 1 \\
\hline Corals Fm & 50 & 0.001 \\
\hline Kilindini sands & between 100 and 300 & between 1E-5 to 0.001 \\
\hline Pliocene Fm & between 1 and 40 & 0.008 \\
\hline Mazeras Fm. outcrop & between 0.1 and 3 & 0.0007 to 0.01 \\
\hline Mkomtuu and Kambe Fm & 1 & $1.00 \mathrm{E}-05$ \\
\hline Palaeochannels & between 0.1 and 1 & 0.0001 \\
\hline Aquitard & 0.6 to 1.1 & 0.01 \\
\hline Mazeras Fm. deep & 0.09 & $1.28 \mathrm{E}+06$ \\
\hline aquifer & 2 & between 1E-7 and 1E-6 \\
\hline
\end{tabular}

Table 2. Obtained hydraulic conductivity and specific storage for the entire model domain after calibration processes with observed data.

Simulated GWLs fit the observed GWL fluctuations in most of the observation wells (Fig. 3). The middle zone of the study area, mainly wells located in the Kilindini sands, are the wells with good fitting data. Regarding the fluctuations through the model period, the drawdown slope of the simulated values is better adjusted than the recovery slope of GWLs. However, there are some simulations of wells located to the north and south, mainly in the Magarini sands, where simulations need a better adjustment.

287 Regarding the tendencies of GWLs in each geological formation, the coastal wells located in the corals show fast but small GWL variations. The water level decline variation of these wells is less than two meters, being the maximum peak of GWL increase after the rainfall event of April 2016 (model time 2708). The simulated

290 GWLs of the wells located in Kilindini and Magarini sands show a different pattern compared with the wells 291 located in Pleistocene corals; GWL variation through the model period is smoother, with a maximum water level decline of around two meters (Fig. 3). These wells show GWL recovery after the drought period in the

293 wake of the long rains wet season of 2017. The wells located in the deep aquifer show more pronounced GWL 294 variations than GWLs in the shallow aquifer units, with a maximum water level decline of four meters (Fig. 3). 
295 The groundwater balance has been also analysed during the 2010-17 simulation period (Fig. 4). From 2014 to 2962017 , the results show that the recharge term in the groundwater balance is the main input of the system and 297 represents $80 \%$ of the total input, which comprises the recharge and river inflow to the aquifer. Groundwater 298 discharge includes groundwater abstraction from the shallow and deep aquifers, lateral aquifer discharge to the sea and groundwater flow from the aquifer to the rivers. In dry years, like 2016 , there is $75 \%$ less recharge compared with 2017, which was a La Niña event. Around $20 \%$ of aquifer recharge comes from the main river

301 channels (Fig. 4).

302 The main output of the system is groundwater discharge to the ocean, which represents around $46 \%$ of total outputs. This output is constant throughout the modelled period, with only $8 \%$ less outflow to the sea in the

304 year of least recharge (2016) compared to 2017. Another important output of the model is the flow coming from 305 drains, which is also nearly constant throughout the model period, even during the years of least recharge. Total groundwater abstraction only represents $0.44 \%$ of total outputs (Fig. 4 ).

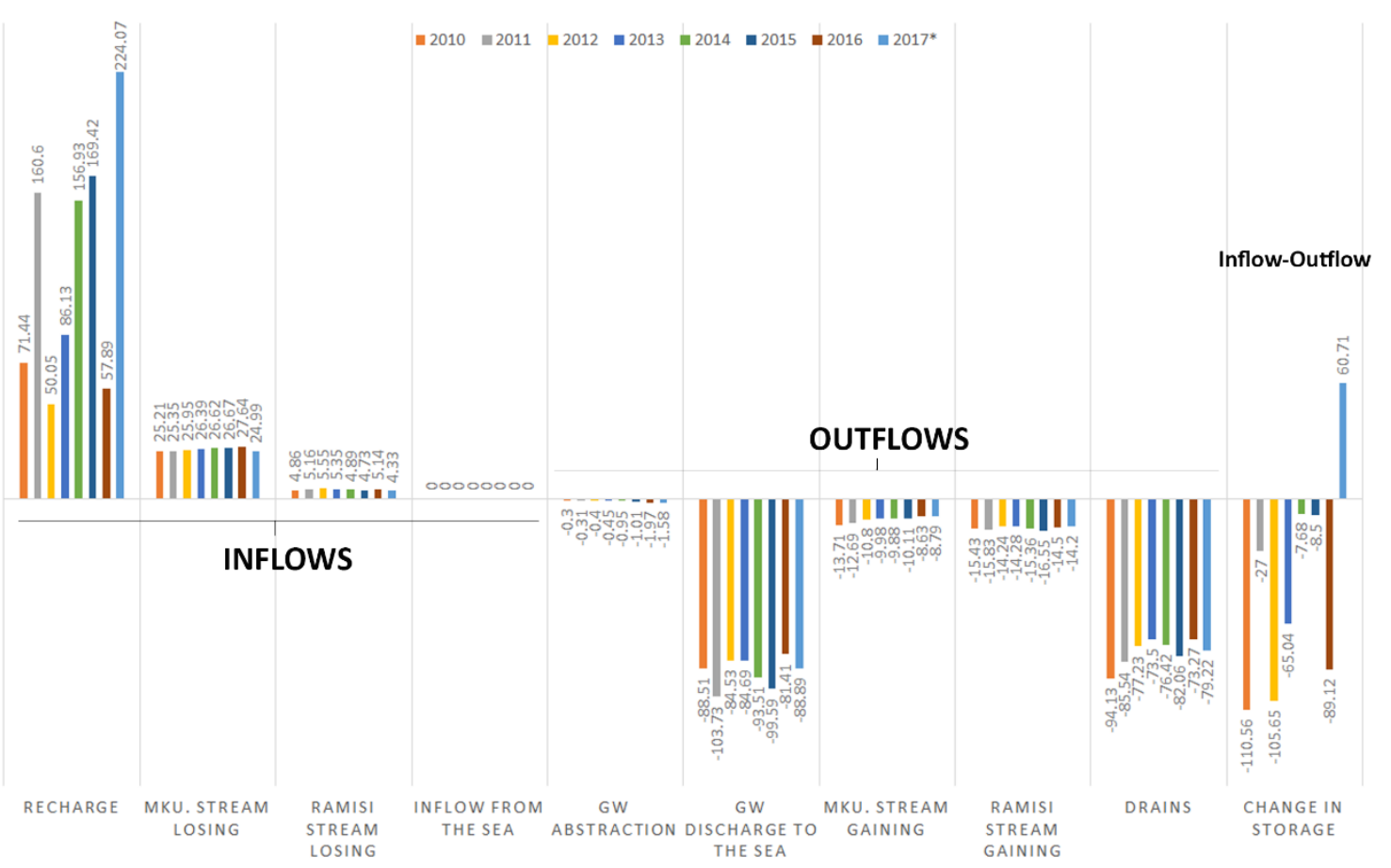

309 Figure 4. Water balance results in hm3/year for the transient simulation. Note: Mku is the Mkurumudzi River. The * in 
311 This net balance is almost constant through the modelled period. Based on the potentiometric map (data not

312 shown), most recharge from surface water infiltrates in the downstream reach of the Mkurumudzi River, where

313 river to aquifer inflow is $52 \%$ higher than the aquifer to river outflow. In contrast, the Ramisi River receives

314 around $67 \%$ more water from the aquifer than the aquifer gets from the river. This is in agreement with the

315 hydrochemistry of samples from the river presented in Ferrer et al. (2019a), where a sample upstream was more

316 saline than a downstream sample, showing surface water dilution with groundwater outflow.

317 The good fit between simulated and observed heads indicates the robustness of the groundwater model.

318 However, there are two areas, one to the south, in Magarini sands, and one to the north, in Kilindini sands,

319 where it was not possible to effectively calibrate simulated groundwater drawdowns (Fig. 1 and 3).

320 The model shows some of the limitations of the conceptual model. The northern area appears to be less

321 influenced by the La Niña event than the central area (see Ferrer et al., 2019a). The calibrated model shows

322 different hydrodynamic behaviour in this area. However, there is no objective geological or hydrogeological

323 evidence that the northern area is significantly different to the central area, particularly with respect to the

324 shallow aquifer system.

325 Simulated GWLs in wells located in the Magarini sands also show a poor fit to observed values. Again, this 326 could be due to conceptual model limitations, such as an incomplete understanding of the full extent and 327 continuity of the palaeochannels; or the potential hydraulic continuity with surrounding formations. Finally, it 328 could also be due to an incomplete understanding of the full extent of the aquitard which separates the 329 groundwater system into the shallow and deep aquifers.

330 However, the model is reasonably effective in simulating the groundwater dynamics of the aquifer. Therefore, 331 it has been used as a tool to analyze the complicated groundwater behavior of the aquifer system under future 332 scenarios.

\section{4. Future scenarios}

334 To simulate the future groundwater resource availability under climate variability and increased abstraction, eight scenarios encompassing the rainfall, temperature, and groundwater demand variables have been

336 considered (Table 3), in order to understand the sensivity of the system to a combination of different changes. 
337 The simulation period covers the hypothetical six year period; the first three years simulate the possible drought periods with low and very low rainfall (1st rain cycle). The persistence within the system of impacts induced

339 under the first change scenario is tested under different recovery scenarios that are defined by the characteristics 340 of the rainfall in the recovery phase ( 2 nd rain cycle). Therefore, the last three years of the future simulations 341 take into account a normal and an above normal precipitation, which is responsible for the recovery of the 342 aquifer system. All the scenarios, except one, are calculated without a temperature increase, since these were 343 considered the most realistic short/medium-term scenarios. A scenario with a $2{ }^{\circ} \mathrm{C}$ temperature increase was 344 generated to study the impact of increased temperature on the aquifer system. Finally, all the scenarios were 345 run for current abstraction volumes and future estimated increase of abstraction to study the effect of abstraction 346 on the system. These eight model scenarios are summarised in Table 3.

\begin{tabular}{|l|l|l|l|l|l|l|l|l|}
\hline $\begin{array}{l}\text { Variable } \\
\text { of future } \\
\text { scenario }\end{array}$ & D_N_0_C & D_N_0_Inc & VD_N_0_C & VD_N_0_Inc & VD_N_2_C & VD_N_2_Inc & VD_W_0_C & $\begin{array}{c}\text { VD_W_0_ } \\
\text { Inc }\end{array}$ \\
\hline $\begin{array}{l}1 \text { st rain } \\
\text { cycle }\end{array}$ & Dry & Dry & Very dry & Very dry & Very dry & Very dry & Very dry & Very dry \\
\hline 2nd rain & Normal & Normal & Normal & Normal & Normal & Normal & Wet & Wet \\
\hline $\begin{array}{l}\text { Temp. } \\
\text { cycle }\end{array}$ & $0^{\circ} \mathrm{C}$ & $0^{\circ} \mathrm{C}$ & $0^{\circ} \mathrm{C}$ & $0^{\circ} \mathrm{C}$ & $2^{\circ} \mathrm{C}$ & $2^{\circ} \mathrm{C}$ & $0^{\circ} \mathrm{C}$ & $0^{\circ} \mathrm{C}$ \\
\hline GW & Current & Increase & Current & Increase (D2) & Current & Increase (D2) & Current & Increase \\
(D) & (D2) & (D) & & (D) & & (D0) & (D2) \\
\hline
\end{tabular}

347 Table 3. Combinations of variables used to simulate the eight numerical flow models to represent different future climate

348 change scenarios.

349 The Shimba Hills (Shimba Hills Centre gauge) record has been the most appropriate "primary" station to apply

350 SPI, as it is located centrally within the study area (Fig. 1). The time data and daily data set records range 351 between 1959 and 2017, with data gaps between 1989 and 99, and in 2002. The mean monthly rainfall measured 352 at Shimba Hills indicates that the seasons for this area are best defined as January-March (JFM), April-June 353 (AMJ), July-September (JAS) and October-December (OND). In order to develop rainfall surfaces that reflect 354 the natural spatial variability of rainfall, the Msambweni DO and Kwale Agricultural Department station 
records were used for matching the time periods defined previously (JFM, AMJ, JAS and OND), as selected for Shimba Hills (Fig. 1).

357 In order to create the temperature time series, two SWAT Global Weather (Soil and Water Assessment Tool) 358 stations have been used to represent the rainfall time series between 1979 and 2015. The TAHMO stations 359 (Trans-African HydroMeteorological Observatory) for Msambweni and Kidongo Gate have been selected, 360 based on proximity, to extend the SWAT data to cover the period $2016-2017$. The net result has been a 361 synthetic temperature time series for each of the three rainfall stations (Shimba Hills, Kwale Agric. and 362 Msambweni DO) used as the temperature input data for the simulation of the rainfall scenarios.

363 Groundwater withdrawal is controlled by the total amount of water allocated to the users by the Water Resources 364 Authority (WRA) through water permits. Groundwater permits ascribe a maximum daily abstraction rate for 365 each borehole ( $\mathrm{m}^{3} /$ day). Actual abstraction may vary season to season. Here, in the absence of actual measured 366 abstraction data, the water permit allocation was used. Four different types of users were identified, namely: (I) 367 mining, with withdrawal from the deep aquifer; (II) irrigated sugar farming, with abstraction from both the 368 shallow and deep aquifers; (III) tourism enterprises, with abstraction from the shallow coastal aquifer; and (IV) 369 medium-scale public water supplies and rural communities, with abstraction from the shallow aquifer. The 370 future abstraction rate for each activity and information sources are detailed in Ferrer et al. 2019b.

\section{$371 \quad$ 5. Results and discussion}

\section{5.1. Effects of rainfall variability}

373 The correlation between projected rainfall and the recharge is not linear (Table 4), confirming that there is no 374 simple direct relationship between average annual rainfall and recharge (Butterworth et al., 1999). This is 375 especially significant for the normal scenario in which the two years show a total precipitation slightly above $3761200 \mathrm{~mm}$, but a range of recharge between 51 and $160 \mathrm{~mm}$. In particular, rainfall during intense but short storms 377 is more effective in driving recharge than lower intensity, more continuous rainfall. The rainfall intensity and 378 distribution through the year influences net recharge, rather than simply the total annual volume of rainfall. 379 Therefore, an intense rainfall event $(>100 \mathrm{~mm})$ on a saturated catchment leads to intense and significant 380 recharge. This is consistent with other studies of the phenomenon (Carter and Parker, 2009; Taylor et al., 2012; 381 Taylor and Jasechko, 2015). Recharge differences across different climate scenarios can be explained by 
394 have the main effect on the GWL in the aquifer. The aquifer system is significantly affected by three years of 395 dry conditions, and needs a wet period in order to recover to the initial state (Fig. 5). The GWL decline over a 396 three year drought period is not reversed when followed by three normal climatic years. The general patterns 397 of GWLs in wells located in the shallow aquifer for different drought future scenarios is similar with little 398 difference in water level decline in the 3-year dry or very dry scenarios. The 3-year wet scenario is required for 399 the aquifer system to recover (Fig. 5).

400 These GWL declines are not the same in all geological formations, so the possible effects are also not the same.

401 In the deep aquifer, GWL decline is higher compared to levels in the shallow aquifer, with a maximum of 10 402 meters after a three drought year. This decline could affect abstraction by the main water-intensive industries 403 in the area supplied from deep boreholes. The cost of pumping groundwater increases approximately linearly 404 with changes in water table depth in groundwater-fed irrigation systems, where energy cost is the main 405 component of water price (Foster et al., 2015). This increased energy cost could increase the sugar and by 406 extension Base Titanium operating costs and consequently product prices.

407 The shallow wells located in the Kilindini and Magarini sands are the most susceptible to desiccation. The GWL 408 decline in these geological formations will be around 5 meters after a three year drought. This will materially 409 influence community well-being, since these communities are largely supplied by handpumps exploiting the 410 shallow aquifer. According to 26 monitoring points used for calibration in which depth is known, $60 \%$ of these 411 would become dry after a long dry period. In fact, $29 \%$ of these wells were dry at the end of the 2016 drought. 412 In prolonged drought periods, shallow wells often fail. This result indicates that only deep hand-dug wells and 413 boreholes are reliable across all seasons and in drought periods. Long drought periods would also influence 414 community economies in the study area which are based mainly on subsistence farming and small-scale 415 livestock-raising. Even though water level decline in wells located in the corals near the coast will not be as 416 significant as in other geological formations, small GWL declines could be sufficient to increase the risk of 417 saline intrusion; climate change, particularly long drought periods, favours increased saline intrusion (Kumar, 418 2012; Okello et al., 2015).

419 Rainfall variability will also influence the river-aquifer relationship, as reducing river flows as outflow from 420 the aquifer to rivers during drought periods declines. The reduction of flow from aquifer to river in a dry year 
421 will be $20 \%$ less compared to a normal climatic year. During prolonged drought periods, this could then affect

422 the dams used for water supply by the main industries (Base Titanium and KISCOL). The use of dams to store

423 surface water by the water-reliant industries, along with the pumping of groundwater underscores the

424 importance of conjunctive use of water resources in the study area.

425 Wet periods are needed for aquifer systems to recover after a long drought period, since average rainfall after a 426 drought is insufficient to lead to full groundwater level recovery. The importance of these wet periods has been 427 recently shown, when the important rains of 2017 led to full recovery of the system after the 2016 La Niña, in 428 which recharge was reduced by $70 \%$. The GWL increase would occur in both aquifer systems and in all 429 geological formations, with higher GWL increase in the Kilindini and Magarini sands. However, important 430 GWL increase during wet period could have a negative effect as major increases in GWLs in the shallow aquifer 431 could reach the bottom level of pit latrines, the most common human excreta disposal systems in the study area, 432 enabling pathogens and other contaminants to directly enter the shallow aquifer. Furthermore, wet periods imply 433 an increase in groundwater discharged to the sea (Supplementary material wet scenario). Although increased 434 discharge to the sea may reduce the saline wedge penetration, it has a negative effect on seagrass diversity 435 (Kamermans et al., 2002). This study found that groundwater outflow influences seagrass species diversity 436 along the East African coast, with less species diversity observed in coastal lagoons with high groundwater 437 outflow.

\subsubsection{Progression of the saline wedge}

439 This sub-section discusses the movement of the saline wedge based on the equation presented in Ferrer et al. 440 (2019a). In this case, reduced recharge caused by a drought period $\left(29,863 \mathrm{~m}^{3} / \mathrm{d}\right)$ and increased abstraction from $4413,616 \mathrm{~m}^{3} / \mathrm{d}$ to $23,589 \mathrm{~m}^{3} / \mathrm{d}$ would move the saline wedge from $0.5 \mathrm{~km}$ inland (where it is located under the 442 current situation) to $2 \mathrm{~km}$ inland under these conditions in the future. At $2 \mathrm{~km}$ inland, the top of the saline water 443 wedge is calculated to be located at $36 \mathrm{~m}$ bgl under current abstraction, but would rise to $16 \mathrm{~m}$ bgl under the 444 future abstraction scenario, affecting the shallow aquifer. These calculations indicate that in other coastal 445 regions with higher withdrawal rates and higher hydraulic conductivities, the saline wedge would penetrate 446 further inland and produce negative impacts for groundwater users. 
447 Since most of the population lives near the coast (Carter and Parker, 2009; Nlend et al., 2018), aquifer 448 salinization near the coast will affect groundwater quality and reduce the availability for a large proportion of 449 the population of Kwale. This will also affect coast hotel water supply and so will impact the country's 450 economy. According to the Kenya Tourist Board (KTB), about $65 \%$ of the tourists coming to Kenya visit the 451 Coast. People living along the Kenyan Coast depend extensively on tourism, which is already being affected 452 by changes in weather and climate (Ongoma and Onyango, 2014). Anecdotally, salinization is already affecting 453 the drinking water of hotels in this area.

\subsection{Effects of temperature increment}

455 The possible future temperature increase of $2^{\circ} \mathrm{C}$ implies a $7 \%$ reduction in recharge when the same future climate and abstraction variables are compared under the scenario with three very dry years followed by three

457 years of normal rainfall. The recharge reduction due to increased temperature is less than $7 \%$ in the wet 458 scenarios (Supplementary material). In this regard, the $2^{\circ} \mathrm{C}$ temperature increase under the wet scenario cannot be observed in GWL trends as the effect of increased temperature on GWLs is less than 0.05 meters. Increasing 460 temperature will produce an increase in PET, which in turn will lead to reduced recharge. However, the effect 461 of increased PET is limited, leading to a water level decrease of around 0.05 meters. Despite the temperature increase insignificantly affecting the GWL decline during drought periods, the increased temperature will affect

463 agriculture. Serdeczny et al. (2015) show that each day during the growing season with a temperature above $46430^{\circ} \mathrm{C}$ reduces yields by $1 \%$ compared to optimal, drought-free, rain-fed conditions. Maize, for example, one of the commonest crops in Sub-Saharan Africa and in the study area, has been found to have a particularly high

466 sensitivity to temperatures above $30^{\circ} \mathrm{C}$ during the growing season. In addition to this, the rainfall reduction 467 during drought periods presented here will affect crop productivity, which will need irrigation, or more 468 irrigation in order to mitigate yield losses.

\subsection{Effects of socio-economic growth}

470 The total anticipated volume abstracted will increase by around $85 \%$ compared with current abstraction

471 (Supplementary material). The percentage of this increment will affect the aquifer storage in each of the future 472 scenarios, reducing the aquifer storage by around $1 \%$ in the dry/normal scenario and $2 \%$ in the very dry/normal 473 and the very dry/wet scenarios. 
474 Focusing only on increased groundwater pumping rates, withdrawal would reduce the volume of groundwater

475 in storage and increase the rate of water level decline across the system by 3 to 5 meters. Increased abstraction

476 also has a local effect on water levels in shallow and deep wells located near intensively-pumped boreholes.

477 The future GWL patterns in wells located in the middle zone near the Base Titanium wellfield show the effect

478 of the increased abstraction scenario, compared with the current abstraction scenarios. Water level decline in

479 the deep aquifer in the middle area may produce a water level decline in shallow wells in the middle area that

480 would be around 0.6 meters, rising to a maximum of 1 meter, compared with wells located far from the wellfield

481 in the same geological formation. In addition (and as with shallow wells located near the wellfield), there are

482 differences in the GWL response in the deep aquifer under both current and increased withdrawal scenarios,

483 depending on the distance of the observation piezometer from the production wells. Piezometers located near

484 production wells show a higher water level decline under future increased abstraction, which would be between

4853 and 5 meters. This is due to the effect of the drawdown cone produced by the pumping wells.

486 As mentioned before, the only scenario in which the system recovers after an important drought period is a

487 drought scenario followed by a wet scenario. In this regard, the future scenario with increased abstraction leads

488 to a delay in the recovery of the system, in both the shallow and deep aquifer; this is more significant in those

489 areas close to the main withdrawals. Therefore, the increased abstraction would affect the shallow aquifer in

490 the middle part of the study area, worsening the situation already produced by climate change. Furthermore,

491 results indicate that even some areas of the deep aquifer, those most affected by abstractions (zone 2), do not

492 recover even after a wet period (Fig. 6). 

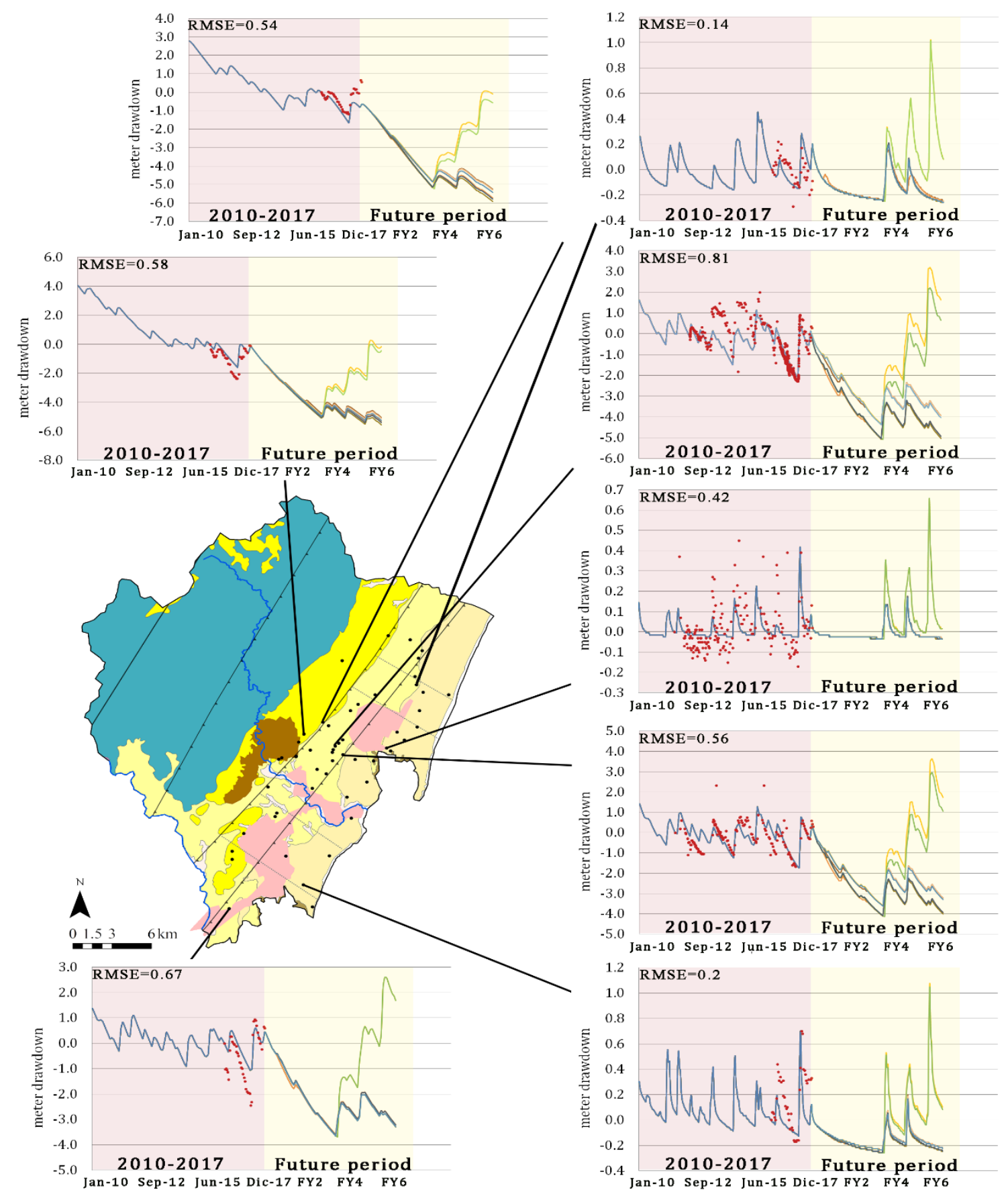

$\mathrm{RMSE}=0.81$
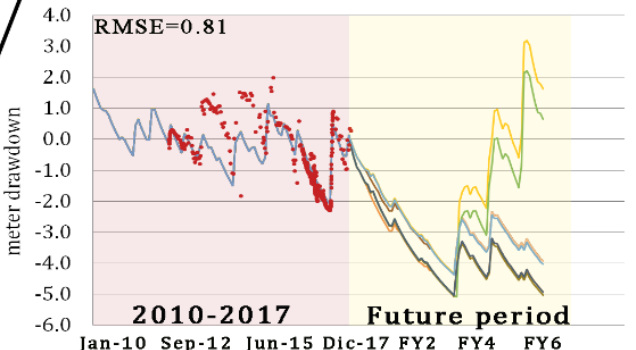

2010-2017 Future period

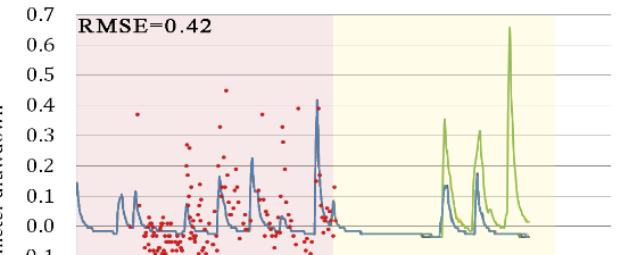

$-0.1$

$-0.2$

2010-2017 Future period Jan-10 Sep-12 Jun-15 Dic-17 FY2 FY4 FY6
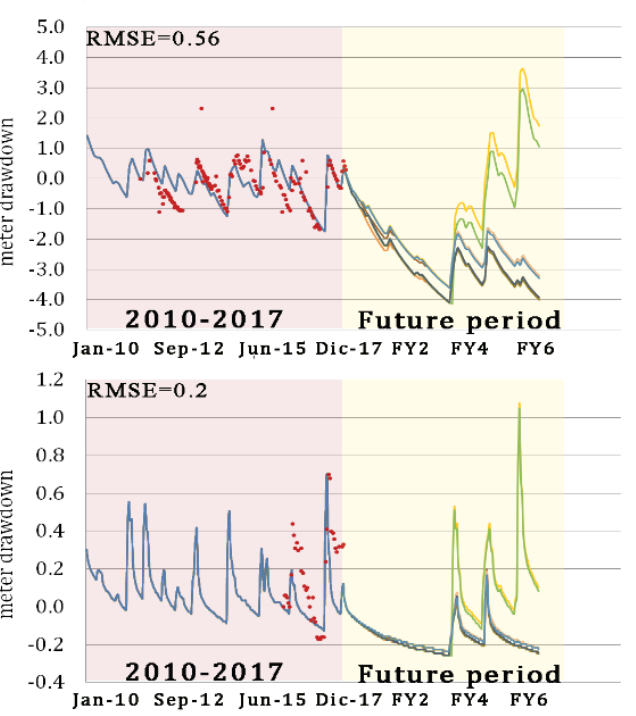

Observed values

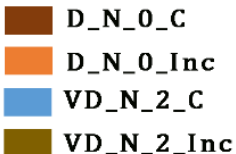

VD_N_O_C

VD_N_O_Inc

VD_W_O_C

VD_W_o_Inc

Figure 5. Observed versus simulated groundwater drawdowns in the shallow aquifer, calibrated for different geological 


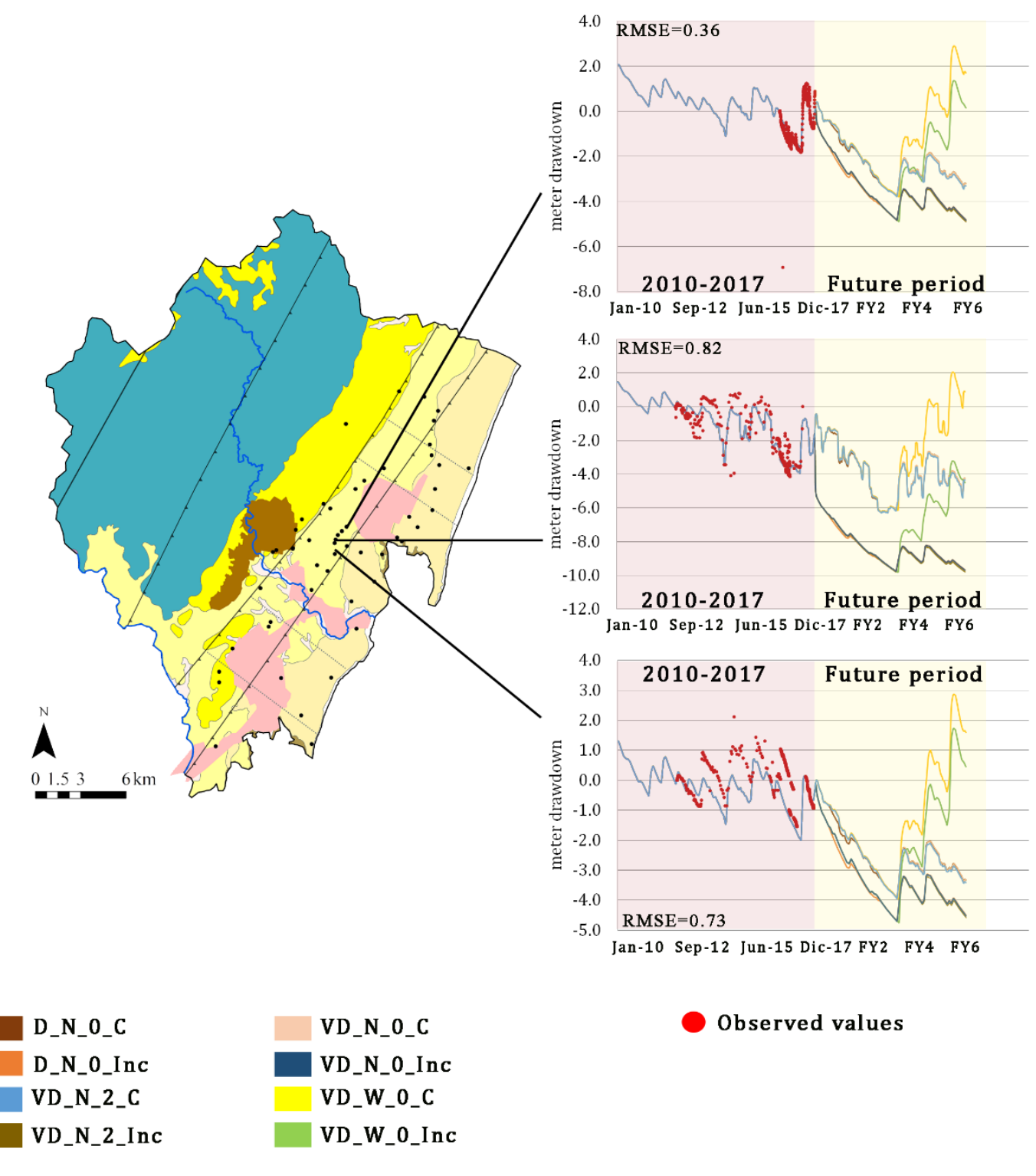

Figure 6. Observed versus simulated groundwater drawdowns, calibrated for wells drilled in the deep aquifer unit from $4992010-2017$ (pink background) and GWLs for six-years simulated future scenarios with yellow background. The units of 500 the RMSSE are meters.

\section{Conclusions and final remarks}

503 This study presents a detailed numerical groundwater flow model of this aquifer on the East African coast,

504 based on a conceptual model developed previously. The numerical model confirms the current sustainability of 
505 the aquifer system and the capability of water levels in the system to recover after some drought events, like 506 the 2016 La Niña event.

507 This model has been used as a tool to empirically test how rainfall and temperature variability could affect

508 recharge in Africa and in aquifer systems by also including increased abstraction due to future socio-economic

509 growth. Expected future withdrawal increases due to economic growth exerts a minimum impact compared

510 with the impacts of anticipated climate variability. Recharge depends on intense rain events with important

511 implications for both dry periods and average rainfall years. Rainfall distribution and high intensity rains are

512 more important in producing effective recharge than the total annual rainfall. GWL trends show that the aquifer

513 needs a rainfall period above 'average' in order to recover GWLs after a long drought period. The impact of

514 increased abstraction is not equal across the study area. Wells near the main abstraction areas, such as the Base

515 Titanium wellfield, show greater declines in GWL under increased withdrawal scenarios. As a result deep

516 piezometers located near the Base Titanium production boreholes show GWL that may not fully recover during

517 wet periods under the projected increased withdrawal rates. However, the effect of increased abstraction on the

518 shallow aquifer system is limited.

519 The future scenarios show the possible impacts on the groundwater system, such as movement of the saltwater 520 wedge, desiccation of community shallow wells and increased cost of deep groundwater withdrawal. These

521 would also affect both the large-scale and community users of groundwater, of particular concern being the

522 impact on the latter, who - absent other sources of supply—will struggle to access reliable potable water.

523 This groundwater depletion is not only related to the consequences of drought or increased withdrawal, but is 524 also related to the economic and social policies of the study area. This should involve all the water users of the 525 area in the process of decision making. These results, which are a long term approach, should help to make 526 management policies and practices that improve human-water relationships by harmonizing the equilibrium 527 between humans and natural water resources, mainly when they are under pressure, such as during a drought.

528 This paper emphasises the minimum data describing an aquifer system needed to ensure sustainable 529 management of groundwater resources. 
532 The authors gratefully acknowledge the collaboration and key data shared by Base Titanium Ltd., and the

533 support of Kenya's Water Resources Authority, the Kwale Country Government, Kwale International Sugar

534 Company Ltd., and Rural Focus Ltd. This research was funded by the UK Government via NERC, ESRC and

535 DFID as part of the Gro for GooD project (UPGro Consortium Grant: NE/M008894/1). 
References

537 Baumann, E., Furey, S., 2013. How three handpumps revolutionised rural water supplies: A brief history of the India Mark II/III, Afridev and the Zimbabwe bush pump.

Butterworth, J.A., Macdonald, D.M.J., Bromley, J., Simmonds, L.P., Lovell, C.J., Mugabe, F., 1999. Hydrological processes and water resources management in a dryland environment III: Groundwater recharge and recession in a shallow weathered aquifer. Hydrol. Earth Syst. Sci. 3, 345-351.

Carter, R.C., Parker, A., 2009. Climate change, population trends and groundwater in Africa. Hydrol. Sci. Sci. Hydrol. 54, 676-689.

Custodio, E., Llamas, M., 1976. Hidrología Subterránea, Omega. ed. Barcelona.

Ferrer, N., Folch, A., Lane, M., Olago, D., Odida, J., Custodio, E., 2019a. Groundwater hydrodynamics of an Eastern Africa coastal aquifer, including La Niña 2016-17 drought. Sci. Total Environ. 661, 575-597.

Ferrer, N., Folch, A., Lane, M., Olago, D., Katuva, J., Thomson, P., Jou, S., Hope, R., Custodio, E., 2019 b. How does water-reliant industry affect groundwater systems in coastal Kenya? Sci. Total Environ. 694.

GoK, 2013. Kenya Country Fact Sheets, 2nd Ed. Government of Kenya, Commission on Revenue Allocation, Nairobi.

Guttman, N.B., 1999. Accepting the standardized precipitation index, Journal Of The American Water Resources Association.

Guttman, N.B., 1998. Comparing the Palmer Drought Index and the Standardized Precipitation Index', Journal of the American Water Resources Association.

Harbaugh, A.W., 2005. MODFLOW-2005, The U. S. Geological Survey Modular Ground- Water Modelthe Ground-Water Flow Process.

Kamermans, P., Hemminga, M.A., Tack, J.F., Mateo, M.A., Marbà, N., Mtolera, M., Stapel, J., Verheyden, A., Van Daele, T., 2002. Groundwater effects on diversity and abundance of lagoonal seagrasses in Kenya and on Zanzibar Island (East Africa). Mar. Ecol. Prog. Ser. 231, 75-83. 
560 Kumar, C.., 2012. Climate Change and Its Impact on Groundwater Resources. Int. J. Eng. Sci. 1, 43-60.

561 Mckee, T.B., Doesken, N.J., Kleist, J., 1993. The relationship of drough frequency and duration to time 562 scales, Eighth Conference on Applied Climatology.

563 Nlend, B., Celle-Jeanton, H., Huneau, F., Ketchemen-Tandia, B., Fantong, W.Y., Ngo Boum-Nkot, S., Etame, 564 J., 2018. The impact of urban development on aquifers in large coastal cities of West Africa: Present $565 \quad$ status and future challenges.

566 Okello, C., Tomasello, B., Greggio, N., Wambiji, N., Antonellini, M., 2015. Impact of population growth and 567 climate change on the freshwater resources of Lamu Island, Kenya. Water (Switzerland) 7, 1264-1290.

568 Ongoma, V., Onyango, O., 2014. A Review of the Future of Tourism in Coastal Kenya: The Challenges and 569 Opportunities Posed by Climate Change. Earth Sci. Clim. Chang. 5, 1-4.

570 Taylor, R.G., Jasechko, S., 2015. Intensive rainfall recharges tropical groundwaters. Environ. Res. Lett. 10, $571 \quad 124015$.

572 Taylor, R.G., Todd, M.C., Kongola, L., Maurice, L., Nahozya, E., Sanga, H., MacDonald, A.M., 2012.

573 Evidence of the dependence of groundwater resources on extreme rainfall in East Africa. Nat. Clim.

$574 \quad$ Chang. 3, 374-378.

575 Winston, R.., 2009. ModelMuse-A graphical user interface for MODFLOW-2005 and PHAST:

$576 \quad$ U.S.Geological Survey Techniques and Methods.

577 


\section{Supplementary material}

579 Figure SM. 1. Hydraulic conductivity discretization for the shallow (a), middle (b) and deep aquifer (c) 

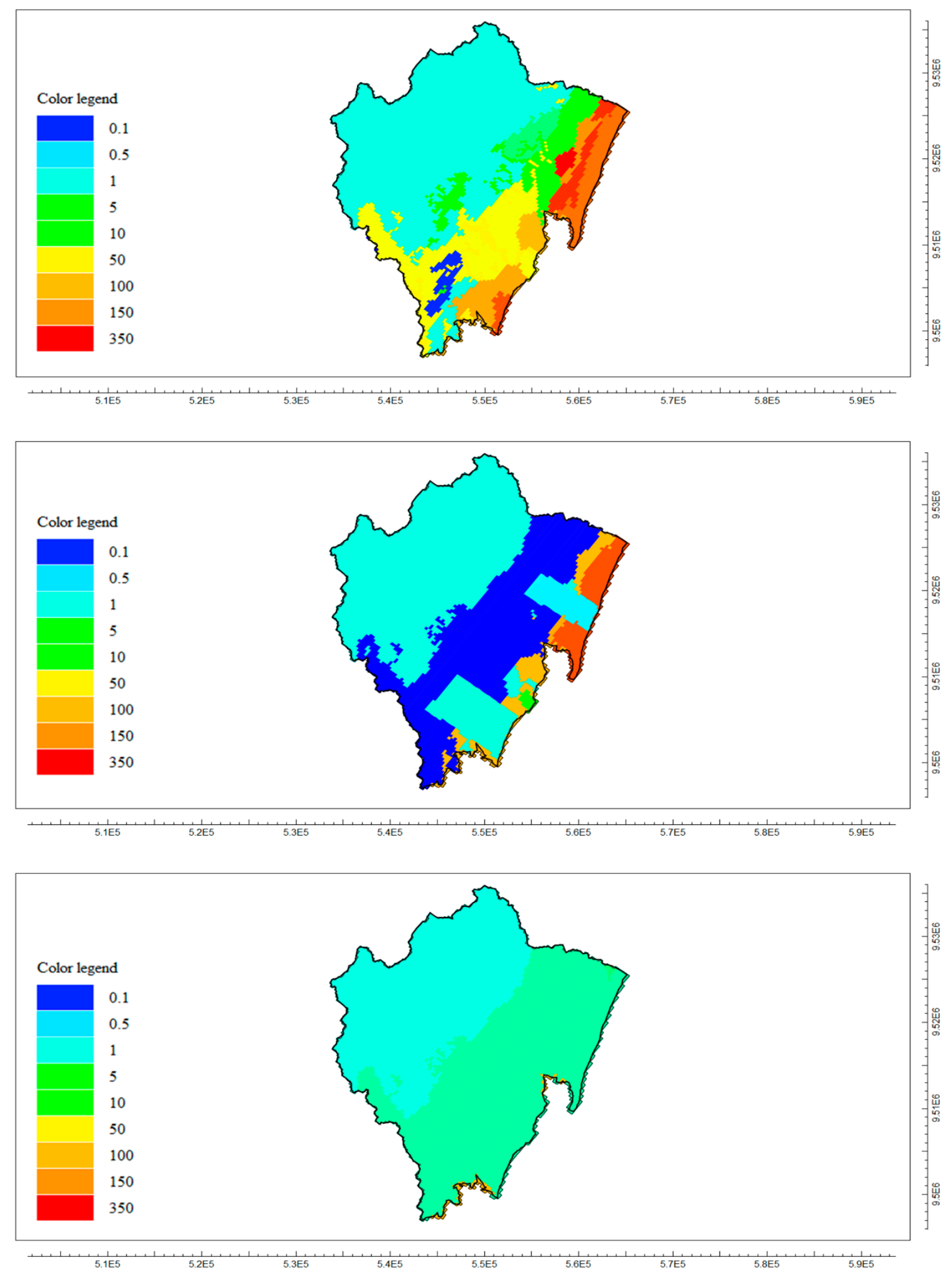


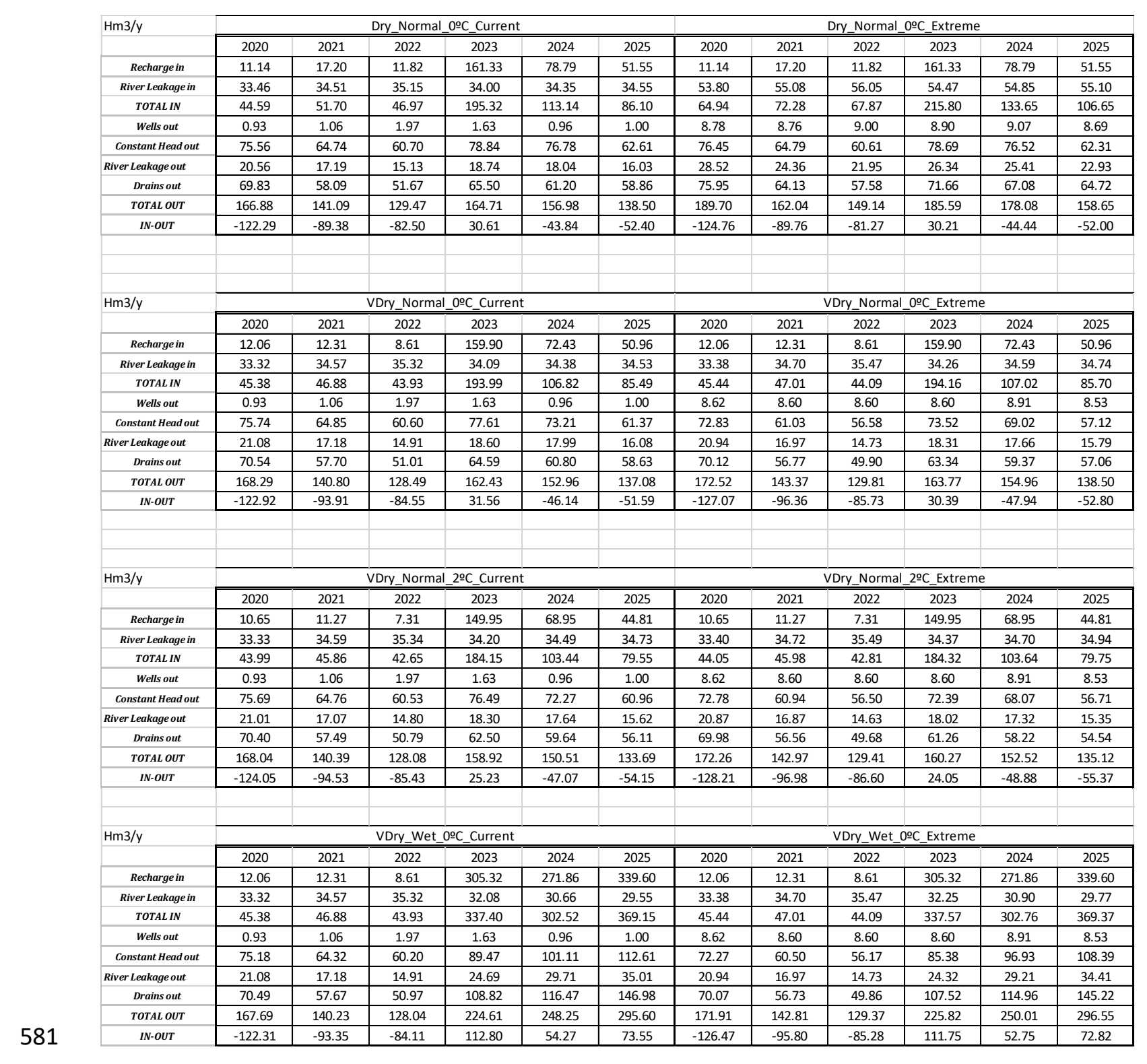

